\title{
Oil-resin glands in Velloziaceae flowers: structure, ontogenesis and secretion
}

\author{
Rachel Sadala-Castilho $^{1} \cdot$ Silvia R. Machado $^{2} \cdot$ Bárbara Sá-Haiad $^{1}$. \\ Heloisa A. Lima ${ }^{1}$
}

Received: 24 October 2015/Accepted: 18 February 2016/Published online: 11 March 2016

(C) Springer-Verlag Wien 2016

\begin{abstract}
Many Velloziaceae flowers present conspicuous glands, whose taxonomic value has already been highlighted. However, until now, their micromorphology, anatomy and ultrastructure have not been investigated, nor have the natures and possible functions of their exudates. Our aim was to investigate distribution, ontogenesis, structure, and secretion mechanisms of glands of Barbacenia flava and Vellozia intermedia and to discuss their possible ecological functions. Samples were prepared according to standard methods for investigations of plant anatomy, scanning electron microscopy, and transmission electron microscopy. Histochemical tests were performed, and focal field observations were made in the study site. The capitate stalked glands on the pedicel, tepals and hypanthium are covered by a sticky secretion that is released in the gland head through the outer periclinal cell walls and cuticle. Secretions are produced in the epidermal and subepidermal cells that contain structural components typical of mixed, mainly lipophilic secretions. Bacteria were found inside the oil-resin gland cells of both species. The Meliponina bees Trigona spinipes and Tetragonisca angustula were observed collecting resin from both species, but were not involved in pollination. Our observations clearly indicate that flower glands of B. flava and
\end{abstract}

Handling editor: Marlies Sazima.

Rachel Sadala-Castilho

rachelsadala@gmail.com

1 Departamento de Botânica, Quinta da Boa Vista, Universidade Federal do Rio de Janeiro, Museu Nacional, Rio de Janeiro, RJ 22940-040, Brazil

2 Departamento de Botânica, Instituto de Biociências, Universidade Estadual Paulista, Caixa Postal 510, Botucatu, SP 18618-000, Brazil
$V$. intermedia are oil-resin secreting and remain active in secretion from very young buds, through to immature fruit. New, smaller glands replace senescent glands by divisions near the base of the original stalk cells. Oil-resin glands have a number of different, but important functions, including the interaction with Meliponina bees, protection against water loss and high temperatures by ultraviolet screening, and anti-desiccant properties.

Keywords Barbacenia flava - Campos Rupestres . Endophytic bacteria $\cdot$ Meliponina $\cdot$ Ultrastructure $\cdot$ Vellozia intermedia

\section{Introduction}

Plant resins are compounds consisting mainly of terpenes and phenols. Primarily, they are materials produced by vegetative organs contained in canals or pockets from which they ooze if the plant suffers some mechanical damage. Resins appear to function against predation, in vegetative tissues, and are also good water repellents. Many bees collect resins exuding from vegetative tissues and carry it to their nests, where it is worked into a coating for the nest walls (Simpson and Neff 1983).

The presentation of floral resin as a reward to female bees of Apidae and Megachilidae has so far been reported in Dalechampia (Euphorbiaceae), Clusia, Chrysochlamys and Tovomitopsis (Clusiaceae) and Clusiella (Calophyllaceae) (Sá-Haiad et al. 2015 and references therein). In the process of collecting floral resin, bees are dusted with pollen and so become effective pollinators (Kearns and Inouye 1993). Floral resins are more easily worked by bees, and also more predictable than vegetative resins (Simpson and Neff 1983). 
Members of Velloziaceae are typical elements of Brazilian Campos Rupestres (Giulietti and Pirani 1988), a neotropical vegetation complex, endemic to Brazil, and located on rocky mountaintops (from 900 to over $2000 \mathrm{~m}$ asl), mainly in the Cerrado and Caatinga provinces of the Brazilian Shield (Alves et al. 2014a). Many Velloziaceae flowers present conspicuous glands, distributed on the pedicel, hypanthium and tepals. Our preliminary observations show that secretions are produced throughout flower and fruit development. Such secretory structures have been described as capitate glandular trichomes (Sazima 1978; Sajo et al. 2010), and most recently as glandular emergences (Montserrat and Mello-Silva 2013). The taxonomic value of these glands has been highlighted by Mello-Silva (1995). Although there are a number of studies that focus on the taxonomy, reproductive biology and floral anatomy of the Velloziaceae species (Mello-Silva 1995, 2004, 2005; Alves et al. 2014b; Sazima and Sazima 1990; Jacobi and Del Sarto 2007; Menezes 1973, 1980, 1988), none have investigated the morphology, anatomy and ultrastructure of these glands, nor have the nature and possible functions of their exudates been discussed.

In this study, we identify the oil-resin nature of the secretion from the glands present in the flowers of Barbacenia flava Mart. ex Schult. and Schult.f. and Vellozia intermedia Seub., and we also describe the origin, structure and lifespan of these glands. Based on the interactions with stingless bees (subtribe Meliponina) and the extreme conditions of the habitats where these species live, we discuss the possible ecological functions of these structures. We also report the presence of endophytic bacteria inside the oil-resin gland cells.

\section{Materials and methods}

\section{Study site and taxa}

This study was conducted at the Parque Estadual de Ibitipoca, located within the municipality of Lima Duarte, Minas Gerais State, SE Brazil (between 21 $40^{\prime} 15^{\prime \prime}-$ $21^{\circ} 43^{\prime} 30^{\prime \prime} \mathrm{S}$ and $\left.43^{\circ} 52^{\prime} 35^{\prime \prime}-43^{\circ} 54^{\prime} 15^{\prime \prime} \mathrm{W}\right)$. The predominant vegetation in the park is characteristic of Campo Rupestre. The climate is altitude tropical, mesothermal, with cold, dry winters (June to September) and high-rainfall summers (December to March). The annual rainfall, $2248 \mathrm{~mm}$, is also high (Rodella and Tarifa 2002).

Barbacenia flava and Vellozia intermedia are herbaceous and occur on rocky and sandy outcrops. Their flowers are trimerous, pedicellate, actinomorphic, perfect, epigynous, with three, fused carpels and septal nectaries. In B. flava, the anthesis is diurnal, the flowers are pale-yellow, odourless and functionally tubular (Fig. 1a, b). In the odouriferous flowers of $V$. intermedia, anthesis is also diurnal, and the tepals are white at the base, changing gradually to blue/violet, towards the apex (Fig. 1c, d).

Voucher specimens were deposited in the herbarium of the Museu Nacional, Universidade Federal do Rio de Janeiro (R).

\section{Structural and ultrastructural studies}

Four stages of the developing flowers of both B. flava and $V$. intermedia were considered: stage 1 , very young flower buds (27 and $33 \mathrm{~mm}$ long, respectively; green tepals); stage 2, flower buds (46 and $52 \mathrm{~mm}$ long; with yellow and violet tepals, respectively); stage 3, freshly open flowers; stage 4 , senescent flowers. Ten replicate samples of each stage were collected for anatomical (five samples) and ultrastructural studies (five samples).

For light microscopy, samples were fixed in $4 \%$ formaldehyde $+2.5 \%$ glutaraldehyde in $0.05 \mathrm{M}$ sodium phosphate buffer, pH 7.2 (Gahan 1984), dehydrated in an ethanol series, embedded in Historesin ${ }^{\circledR}$ (Leica, Wetzlar, Germany) in accordance with the manufacturer's recommended procedure, and sectioned with glass knives at 1-3 $\mu \mathrm{m}$ on a RM2255 (Leica) rotary microtome. The sections were stained with toluidine blue $\mathrm{O}$ (Feder and O'Brien 1968). Measurements and photomicrographs were obtained using an Olympus BX-51 microscope (Olympus, Tokyo, Japan) with the image-capture system Q color5 and Image-ProExpress software (Media Cybernetics Inc., Silver Spring, Maryland, USA).

Histochemical tests were carried out to detect the presence of lipophilic compounds using Sudan III and IV (Jensen 1962); starch using Lugol (Langeron 1949); sugars using Fehling's reagent (Maclean and Ivemey-Cook 1952); phenolic compounds using potassium dichromate (Gabe 1968); proteins using xylidine Ponceau (Cortelazzo and Vidal 1991; Amaral et al. 2001); mucilage using ruthenium red (Langeron 1949); polysaccharides, using the periodic acid-Schiff's reagent reaction (Taboga and Vilamaior 2013); lignin using phloroglucin + $\mathrm{HCl}$ (Johansen 1940); cellulose and suberin using iodated zinc chloride (Jensen 1962); and resin using copper acetate (Johansen 1940).

For scanning electron microscopy (SEM), samples were fixed in glutaraldehyde $(2.5 \%$ with $0.1 \mathrm{M}$ phosphate buffer, $\mathrm{pH}$ 7.3), post-fixed with $0.5 \%$ osmium tetroxide in the same buffer, dehydrated in an ethanol series, critical-point dried using a Balzers Union CPD 020 critical-point dryer with $\mathrm{CO}_{2}$, gold coated using a Bal-Tec SCD 050 vacuum sputter-coater and examined using a FEI QUANTA 200 microscope (FEI, Hillsboro, OR, USA).

For transmission electron microscopy (TEM), samples were fixed in glutaraldehyde $(2.5 \%$ with $0.1 \mathrm{M}$ phosphate buffer, pH 7.3) and left overnight at $4{ }^{\circ} \mathrm{C}$. They were then 

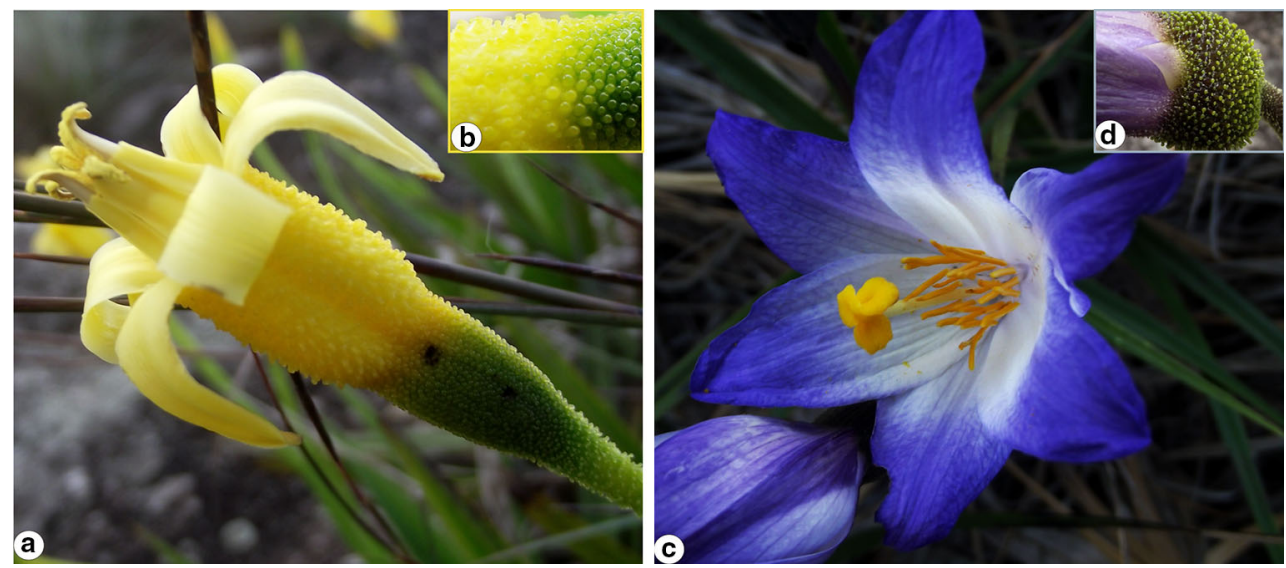

Fig. 1 Barbacenia flava $(\mathbf{a}, \mathbf{b})$; Vellozia intermedia $(\mathbf{c}, \mathbf{d})$ : a flower in lateral view, b detail of the glands on the outer surface of the hypanthium; c flower in frontal view; $\mathbf{d}$ detail of the glands on the outer surface of the hypanthium

post-fixed with $1 \%$ osmium tetroxide in the same buffer for $2 \mathrm{~h}$ at room temperature, dehydrated in a graded series of acetone solutions and embedded in Araldite resin. Ultrathin sections were stained with uranyl acetate and lead citrate (Reynolds 1963) and observed under a Tecnai Spirit (FEI) microscope.

All images were processed using Adobe Photoshop 7.0.

\section{Determination of bacteria profiles per vacuole area}

For both analysed species, cell electron micrographs (obtained by TEM) for each of the four developmental stages related to the glands' secretory period, were scored to determine the area of the bacteria-containing vacuoles. Bacteria profiles in each vacuole were counted. The areas of the vacuoles were determined by morphometric analysis, using ImageJ software (Schindelin et al. 2012). Then, the mean ratios between bacteria profiles observed and the area of the vacuoles were calculated.

\section{Field observations}

Diurnal focal field observations (Dafni et al. 2005) were made from 2013 to 2015, on 40, previously selected, adult individuals of $B$. flava and 40 of $V$. intermedia, to verify the occurrence of interaction between oil-resin glands and fauna.

\section{Results}

\section{Morphology, distribution and histochemistry of glands}

The glands (Fig. 2a-h) are stalked, rarely sessile, capitate and not vascularised; they are sparsely distributed along the peduncle, densely concentrated on the hypanthium surface, and in specific areas on the tepals. In B. flava, such glands occur on both sides of the outer tepals (Fig. 2e, f), being less frequent on the adaxial surfaces, where they are limited to the distal portions and have reduced or even absent stalks (Fig. 2f). On the inner tepals, they are restricted to the abaxial surfaces, and only on the portions not covered by the outer tepals (exposed) during the bud stage. In V. intermedia, they occur on the abaxial surfaces of the proximal and distal (Fig. $2 \mathrm{~g}$ ) portions of the external tepals.

The glands present the same colour of the organ where they are inserted. In B. flava they are light green on the hypanthium and yellow on the tepals (Figs. 1b, 2a). In the $V$. intermedia hypanthium, the glands have a light green head and a brownish-green stalk (Figs. 1d, 2b). In the tepals they are a lilac colour. In both species the hypanthia are covered by an abundant hyaline, sticky secretion (Fig. 2a, b) from a very young flower bud until the moment before fruit dehiscence (ca. 70 days in B. flava and 60 days in $V$. intermedia). This period is not related to the life span of a gland. Glands active in secretion are always present, being continuously replaced. The viscid secretion is released in the distal portion of the gland head (Fig. 2c, d). Besides oil and resin in the protoplast of the secretory cells and in secretions on the gland surface, phenolic compounds, mucilage, proteins and sugars were also detected histochemically (Table 1).

\section{Ontogenesis}

Results on ontogenesis are restricted to the hypanthium glands.

The glands are formed on the abaxial surface of the hypanthium where they are observed at different developmental stages, characterising the asynchrony of this process (Fig. 3a, b). In the initial stages of flower development, the 

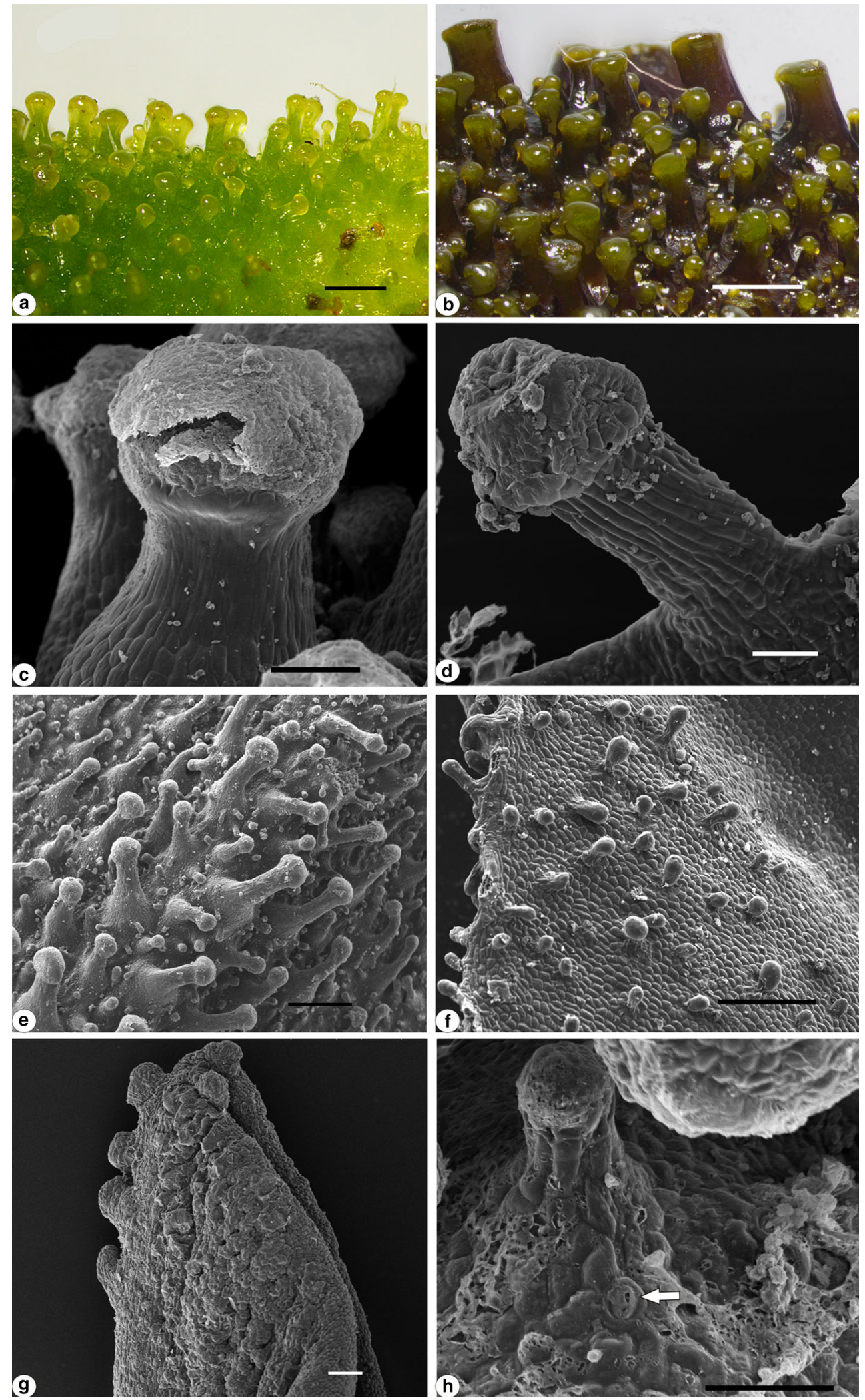

Fig. 2 Barbacenia flava (a, c, e, f, h); Vellozia intermedia $(\mathbf{b}, \mathbf{d}, \mathbf{g})$ : $\mathbf{a}, \mathbf{b}$ hypanthium glands; $\mathbf{c}, \mathbf{d}$ gland, in lateral view. Note the viscid secretion released in the distal portion of the gland head; $\mathbf{e}, \mathbf{f}$ detail of external tepal in frontal view: e abaxial surface, $\mathbf{f}$ adaxial surface; $\mathbf{g}$ detail of abaxial surface in the distal portion of the external tepals, in lateral view; $\mathbf{h}$ gland covered by secretion. Note a paracytic stomate at the base of the gland stalk (white arrow). Scale bars $1 \mathrm{~mm}$ in $\mathbf{a} ; 50 \mu \mathrm{m}$ in $\mathbf{d}, \mathbf{h} ; 100 \mu \mathrm{m}$ in $\mathbf{c}, \mathbf{g} ; 200 \mu \mathrm{m}$ in $\mathbf{e}, \mathbf{f}$ and $500 \mu \mathrm{m}$ in $\mathbf{b}$ 
Table 1 Results of histochemical tests carried out on the hypanthium glands of Vellozia intermedia and Barbacenia flava

\begin{tabular}{|c|c|c|c|c|c|c|}
\hline \multirow[t]{2}{*}{ Reagent } & \multirow[t]{2}{*}{ Substance } & \multirow[t]{2}{*}{ Colour } & \multicolumn{2}{|l|}{ B. flava } & \multicolumn{2}{|l|}{$V$. intermedia } \\
\hline & & & Glands & Secretion & Glands & Secretion \\
\hline Copper acetate & Resin & Greenish & + & + & $+($ brownish-green $)$ & + (brownish-green) \\
\hline Sudan III & Lipophilic compounds & Orange-red & + & + & + & + \\
\hline Sudan IV & Lipophilic compounds & Orange-red & + & + & + & + \\
\hline Ruthenium red & Pectic substances & Pink to purple & + & + & + & + \\
\hline Xylidine Ponceau & Proteins & Red & + & + & + & + \\
\hline Lugol & Starch & Violet & + & - & + & - \\
\hline Fehling's reagent & Sugars & Brown & + & - & + & - \\
\hline Potassium dichromate & Phenolic compounds & Brown & + & + & + & + \\
\hline \multirow[t]{2}{*}{ Periodic acid-Schiff's reagent } & Polysaccharides & Magenta & + & + & + & + \\
\hline & & & \multicolumn{2}{|c|}{$\begin{array}{l}\text { B. flava Gland stalk cell } \\
\text { walls }\end{array}$} & \multicolumn{2}{|c|}{ V. intermedia Gland stalk cell walls } \\
\hline \multirow[t]{2}{*}{ Iodated zinc chloride } & Cellulose & Blue & \multicolumn{2}{|l|}{-} & \multicolumn{2}{|l|}{-} \\
\hline & Suberin & Yellow & \multicolumn{2}{|l|}{+} & \multicolumn{2}{|l|}{+} \\
\hline Phloroglucin $+\mathrm{HCl}$ & Lignin & Red & \multicolumn{2}{|l|}{-} & \multicolumn{2}{|l|}{-} \\
\hline
\end{tabular}

+ , positive; - , negative

hypanthium in cross-section, shows a layer of protodermal cells with quadrangular outlines. The gland differentiation begins with the proliferation of protodermal cells, which by successive divisions, form a protuberance. The subepidermal cells, just below the protuberance, originating from the ground meristem, undergo successive oblique and periclinal divisions that lead to the formation of the central parenchyma region of the future stalk. Thus, in longitudinal section, the base of the glandular primordium may contain three to four cells, the two outermost being of protodermal origin and the one or two inner cells originating from the ground parenchyma (Fig. 3c, d). This fact characterises the glands as emergences. The maturity stage of a gland may be uncoupled from the organ with which it is associated. New glands are formed continuously on the hypanthium. In addition, new glands may arise from the stalks of developed glands, by epidermal and parenchymatic cells divisions (Fig. 3e, f).

In the mature gland, the stalk is cylindrical, varies in thickness and length, and has paracytic stomata at the base (Figs. 2h, 3d, f). It has a thin cuticle, one-layered epidermis, and, in longitudinal section, parenchyma layers with axially elongated rectangular cells with suberous walls, especially in B. flava. In this species, the stalk is wider at the base and narrows towards the apex. Cell wall suberisation is more pronounced in the distal layers of both epidermal and parenchyma cells, positioned below the secretory head (Fig. 3g, h). In V. intermedia, in longitudinal section, the head has a plano-convex outline (Fig. 3b), but a convex outline in B. flava (Fig. 3a). It has a thick cuticle, a one-layered epidermis with quadrangular cells, and a parenchymatous core.

\section{Ultrastructure and secretion}

From the flower-bud stage to early fruit set, glands at various stages of development are seen side by side. Actively secreting glands have already been reported on very young flower buds. Thus, the four developmental stages described here are related primarily to head cells during the glands' secretory period, and are independent of the flower developmental stages considered in this study.

Stage A: In B. flava, the glands possess epidermal cells having very thick cuticles that penetrate between the anticlinal walls, forming flanges (Fig. 4a). All secreting cells, both epidermal and parenchymatous, have meristematic aspects and dense walls with sinuous outlines (Fig. 4a). Epidermal cells connect to one another and to parenchyma cells via plasmodesmata (not shown). The voluminous nuclei have circular to sinuous outlines, nucleoli, and show clear distinction between euchromatin and heterochromatin (Fig. 4a, c, h). The vacuome consists of numerous and small vacuoles, some containing fibrillar material, probably polysaccharides, suggested by positive result of the periodic acid-Schiff's reaction (see Table 1). The cytoplasm is very dense and organelle-rich. The presence of polymorphic plastids is remarkable, having dense stroma and being devoid of inner membranes, along with plastids containing starch grains and oil bodies scattered throughout the cytoplasm (Fig. 4b, d). Golgi bodies, smooth endoplasmic reticulum with dense contents, globular to elongated mitochondria, polyribosomes, and vesicles containing fibrillar material are also observed (Fig. 4c, d). In $V$. intermedia, glands present secretory cells that are almost tabular in shape. Their cytoplasm is rich in 

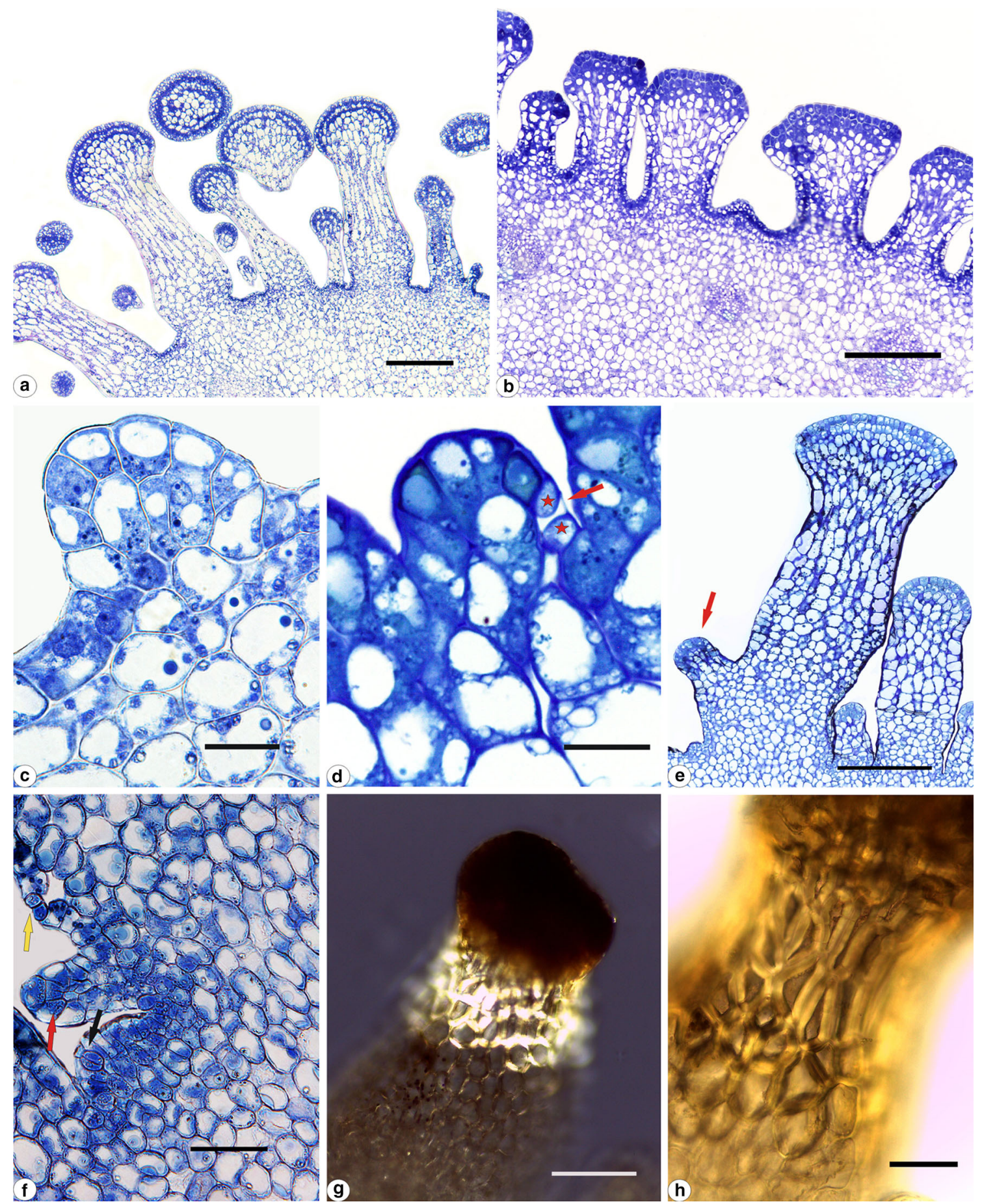

Fig. 3 Hypanthium glands of Barbacenia flava (a, c, e-h) and Vellozia intermedia $(\mathbf{b}, \mathbf{d})$, in longitudinal section: $\mathbf{a}, \mathbf{b}$ general view of glands on abaxial surface; c, d glandular primordia. Note an immature stomate (red arrow), the two separated guard cells (red stars) and the pore yet covered by the outer cuticle, in $\mathbf{d}$; $\mathbf{e}, \mathbf{f}$ new gland (red arrow) arising from the stalk of developed gland. Note a

polymorphic plastids containing electron-dense inclusions (Fig. 4e), polyribosomes and smooth endoplasmic reticulum, sometimes with electron-dense contents (Fig. 4f), stomate at the stalk base (yellow arrow) and an immature stomate in paradermal view (black arrow), in $\mathbf{f} ; \mathbf{g}, \mathbf{h}$ cell wall suberisation in stalk distal cell layers, under polarised light, in $\mathbf{g}$, and subjected to the iodated zinc chloride test, in $\mathbf{h}$. Scale bars $20 \mu \mathrm{m}$ in $\mathbf{c}, \mathbf{d} ; 50 \mu \mathrm{m}$ in $\mathbf{f}$, $\mathbf{h} ; 100 \mu \mathrm{m}$ in $\mathbf{g}$ and $200 \mu \mathrm{m}$ in $\mathbf{a}, \mathbf{b}, \mathbf{e}$

probably resin. Globular to elongated mitochondria are found close to the plastids, nuclei and plasma membrane (Fig. 4f, h, i). In this stage, amyloplasts and lipid bodies are 

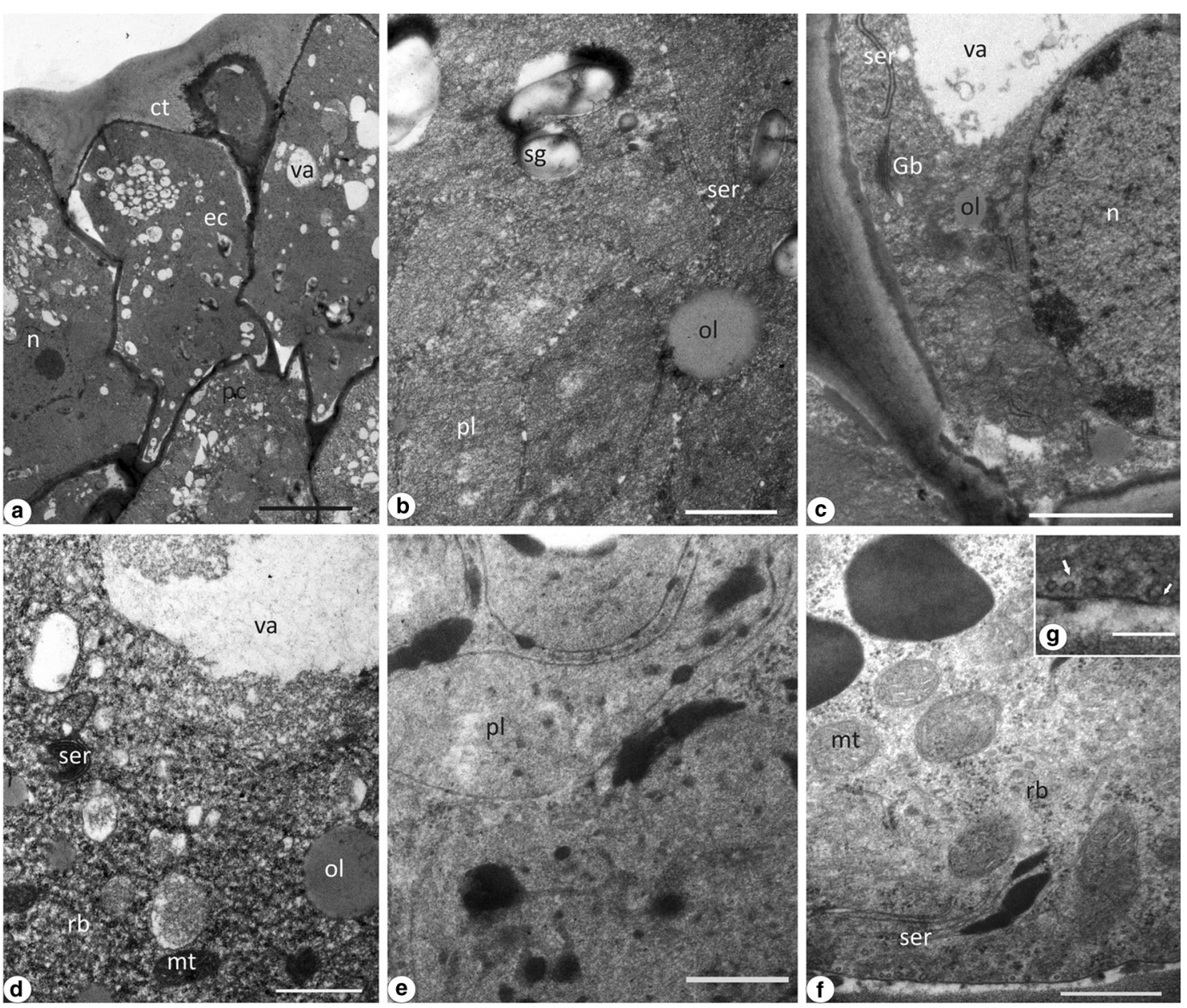

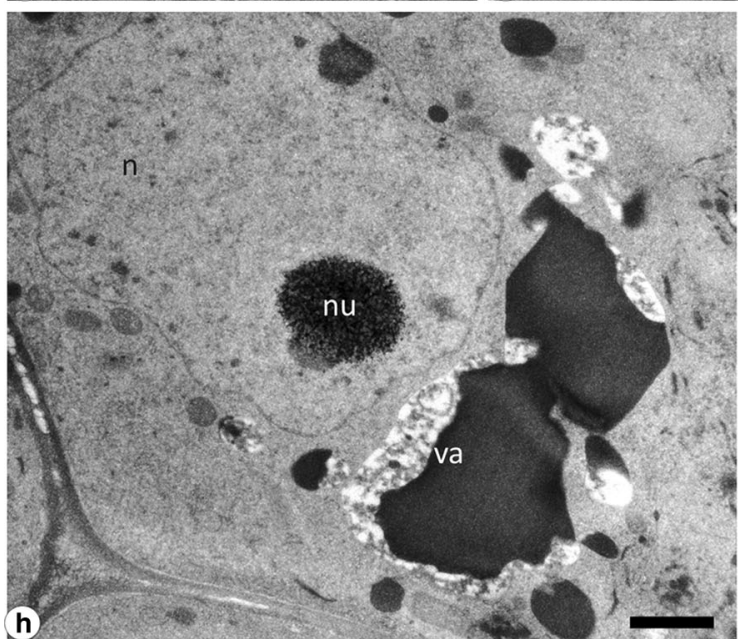

Fig. 4 Secretory cells of glands (stage A) of Barbacenia flava (ad) and Vellozia intermedia (e-h): a epidermal cells with very thick cuticles; b parenchyma cell showing polymorphic plastids, plastids containing starch grains and oil body; c parenchyma cell showing Golgi bodies, smooth endoplasmic reticulum and oil bodies; d parenchyma cell showing smooth endoplasmic reticulum, mitochondria, polyribosomes, and vesicles containing fibrillar material; e parenchyma cell showing polymorphic plastids; f parenchyma cell showing polyribosomes, smooth endoplasmic reticulum with electron-dense contents and mitochondria; $\mathbf{g}$ detail of $\mathbf{f}$, showing vesicles

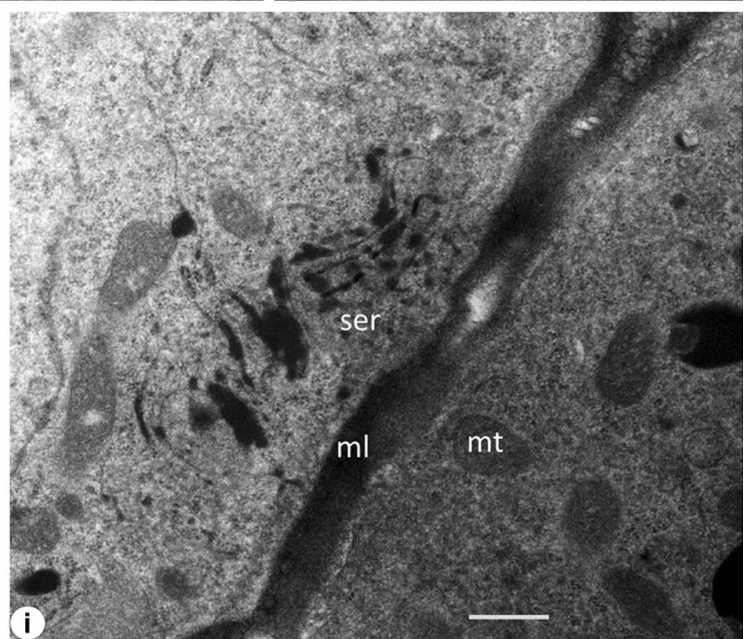

close to, or fused to, the plasma membrane (white arrows); h parenchyma cell showing conspicuous nucleus and vacuole with fibrillar and electron-dense amorphous contents; i epidermal cells. Note the presence of gaps in the middle lamella ( $c t$ cuticle, ec epidermal cell, $G b$ Golgi bodies, $m l$ middle lamella, $m t$ mitochondria, $n$ nucleus, $n u$ nucleolus, $o l$ oil body, $p c$ parenchyma cell, $p l$ plastid, $r b$ ribosome, ser smooth endoplasmic reticulum, $s g$ starch grain, $v a$ vacuole). Scale bars $125 \mathrm{~nm}$ in $\mathbf{g} ; 500 \mathrm{~nm}$ in $\mathbf{e}, \mathbf{f}, \mathbf{h} ; 1 \mu \mathrm{m}$ in $\mathbf{c}, \mathbf{d}, \mathbf{g}$; $2 \mu \mathrm{m}$ in $\mathbf{c}$ and $5 \mu \mathrm{m}$ in $\mathbf{a}$ 
scarce. The vacuoles, in addition to fibrillar material, also exhibit electron-dense amorphous content, probably phenolic compounds (Fig. 4f, h). In the parenchymatous secretory cells, the displacement of the plasma membrane and formation of periplasmic spaces containing dense materials and lomasomes can be observed (Fig. 4f). In addition noted is the presence of gaps in the middle lamella (Fig. 4i) or even its complete dissolution. Vesicles close to, or fused to, the plasma membrane are also observed (Fig. 4g).

Stage B: In secretory epidermal cells of glands from $B$. flava, the plasma membrane is displaced, moving away from the outer periclinal and anticlinal cell walls and giving rise to a large periplasmic space, where components of the secretion can be observed (Fig. 5a, b). Large numbers of oil bodies are also noted, dispersed in the cytoplasm, within vacuoles, passing through the plasma membrane, and in the periplasmic space (Fig. 5b). Noteworthy is the presence of polyribosomes, smooth endoplasmic reticulum and ovoid plastids containing small starch grains, some showing signs of degradation (Fig. 5a, b). The amyloplasts are frequent. In this stage, secretory cells in the glands of $V$. intermedia exhibit polymorphic plastids (Fig. 5d), mitochondria, rough endoplasmic reticulum and vacuoles with fibrillar and electron-dense contents (Fig. 5c). Polymorphic plastids are elongated and contain dense stroma and small starch grains (Fig. 5d).

Stage C: In epidermal cells of glands from B. flava, the cuticle presents a dense fibrillar network, giving it a spongy appearance (Fig. 5e). The abundance of smooth endoplasmic reticulum containing electron-dense material and fusion of multivesicular bodies with the plasma membrane are noticeable (Fig. 5f). In secretory parenchyma cells of mature glands of $V$. intermedia, the conspicuous cytoplasm was almost completely filled with proliferate, smooth endoplasmic reticulum (Fig. $5 \mathrm{~g}$ ) and polyribosomes (Fig. 5h). Larger vacuole, traversed by transvacuolar strands, is filled with oil bodies (Fig. 5i).

Stage D: Senescent gland cells of both species exhibit intact cuticle suggesting the secretion passes through the outer periclinal walls and the cuticle. Epidermal cells have a single, large central vacuole, a reduced cytoplasm restricted to their periphery, and poorly defined organelles (not shown).

\section{Bacteria}

In all samples of both species, spherical bacteria were found inside the oil-resin gland cells, throughout the four developmental stages described here (stages A-D). Bacteria occurred scattered through the cytoplasm (mainly in stage A) (Fig. 6a) and clustered or scattered inside vacuoles of the head (Fig. 6b, c) and stalk cells (Fig. 6d, f), but their size and abundance are greater within parenchyma cell vacuoles. At high magnification, bacteria exhibit a surface meshwork of fine fibrillar material, identified as polysaccharide, characterising the glycocalyx (Fig. 6d); plasma membrane (Fig. 6d), and translucent cytoplasmic regions (Fig. 6e). The bacterial population seems to increase through the development of the gland, and bacteria are more abundant at stages $\mathrm{C}$ and $\mathrm{D}$ (Table 2). Signs of a binary fission were commonly observed (Fig. 6f), suggesting division within the bacterial population.

\section{Interaction between bees and oil-resin glands}

Field observations made over two consecutive flowering periods. These showed that Tetragonisca angustula Latreille 1811 (Fig. 7a) and Trigona spinipes Fabricius 1793 (Fig. 7b) collect the secretions exuded by the glands from both species, especially from those of the hypanthium. Bees do not contact the reproductive structures when collecting resin. The visits are time consuming (ca. $1 \mathrm{~min}$ ) and the resin collected is carried on the third pair of legs. Oil-resin collection is more common on sunny and hot days. Trigona spinipes also visits flowers to collect pollen, acting as a thief and often causing damage to the perigonium.

\section{Discussion}

The glands on the hypanthium and tepals of the species studied are oil-resin producers. Resin secretion by glandular stalked capitate trichomes, on both the vegetative and floral parts of the plant, has been described for Cannabis and Humulus of the Cannabinaceae (Hammond and Mahlberg 1973). In this study, the oil-resin glands are typical emergences formed by the epidermal and parenchymatous tissues (Evert 2006). These glands comprise a multiseriate secretory head and a stalk of variable size, and are similar in structure to resin secretory emergences described in the calyx of Plumbago auriculata Lam. (referred to as Plumbago capensis, Fahn 1979). As reported for that species, the secretion in B. flava and $V$. intermedia is released by the secretory head. However, in Plumbago the resin is released through blisters in various parts of the head (Fahn 1979), whereas in our two species the secretion traverses the intact cuticle, which remains adhered to the outer periclinal cell walls, in the distal region of the head.

The histochemical results reveal that the secretion produced by the tepals and hypanthium glands in both species is of a mixed nature, with hydrophilic components (polysaccharides, phenolic compounds and proteins) in addition to lipophilic ones (essential oils and resins). It is well known that such hydrophilic secretions are composed 

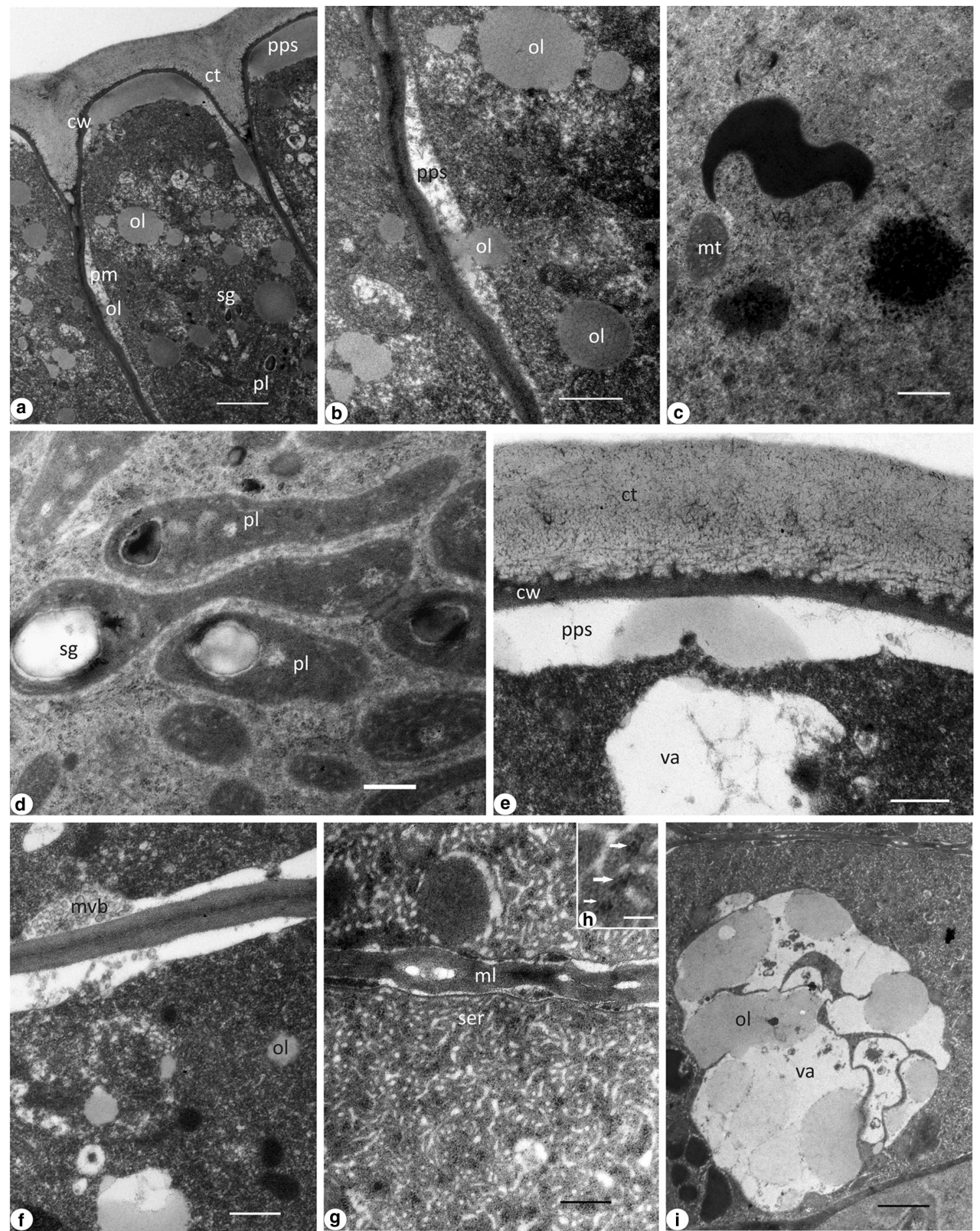

Fig. 5 Secretory cells of glands (stage B, a-d and stage C, e-h) of Barbacenia flava (a, b, e, f) and Vellozia intermedia $(\mathbf{c}, \mathbf{d}, \mathbf{g}, \mathbf{h})$ : a epidermal cells with large periplasmic spaces with secretions; b epidermal cells showing oil bodies, dispersed in the cytoplasm, passing through the plasma membrane, and in the periplasmic spaces; c epidermal cell showing vacuole with fibrillar and electron-dense content; $\mathbf{d}$ epidermal cell showing polymorphic plastids; e epidermal cell with cuticle presenting a dense fibrillar network; $\mathbf{f}$ epidermal cell showing a multivesicular body in close proximity to the cell membrane; $\mathbf{g}$ parenchyma cell showing cytoplasm with proliferate smooth endoplasmic reticulum and polyribosomes; $\mathbf{h}$ detail of $\mathrm{g}$, showing polyribosomes (white arrows); i parenchyma cell showing vacuole filled with oil bodies and cytoplasm debris ( $c w$ cell wall, $m v b$ multivesicular bodies, $p m$ plasma membrane, $p p s$ periplasmic space). Scale bars $125 \mathrm{~nm}$ in $\mathbf{h} ; 500 \mathrm{~nm}$ in $\mathbf{c}, \mathbf{d}, \mathbf{e}, \mathbf{f}, \mathbf{g} ; 1 \mu \mathrm{m}$ in $\mathbf{b}$ and $2 \mu \mathrm{m}$ in a, h 

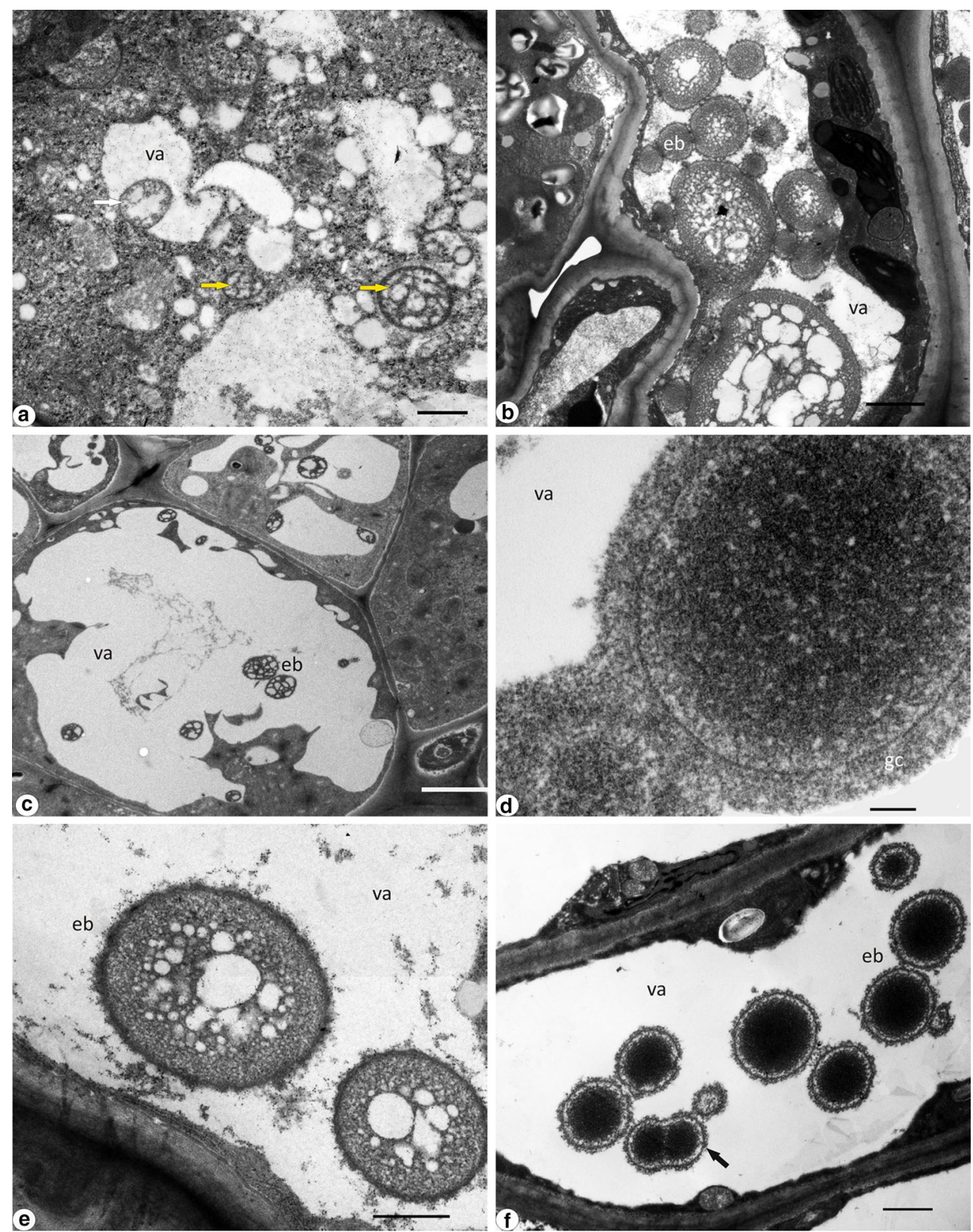

Fig. 6 Barbacenia flava (a, b, d-f); Vellozia intermedia (c): a parenchyma cell from the gland head (stage A). Note the bacteria scattered through the cytoplasm (yellow arrows) and inside a vacuole (white arrow); $\mathbf{b}, \mathbf{c}$ bacteria inside the vacuole of parenchyma cells from the gland head (stage B); $\mathbf{d}$ bacteria inside the vacuole of a parenchyma cell from the gland stalk (stage D). Note the glycocalyx;

of several chemical substances which are sticky to the touch, and can be classified as mucilage (Johansen 1940). Among other functions, mucilage improves the protection against desiccation of meristematic tissues and young organs (Gregory and Baas 1989). Both species showed the same results for the histochemical tests; in B. flava, a positive reaction to the acetate cupric test showed a greenish tinge, whereas in $V$. intermedia it was brownish e bacteria inside the vacuole of a parenchyma cell from the gland head (stage C). Note the presence of bacteria-translucent cytoplasmic regions; $\mathbf{f}$ bacteria inside the vacuole of a parenchyma cell from the gland stalk (stage D). Note the signs of binary fission (black arrow) ( $e b$ endophytic bacteria, $g c$ glycocalyx, $v a$ vacuole). Scale bars $200 \mathrm{~nm}$ in $\mathbf{d} ; 1 \mu \mathrm{m}$ in $\mathbf{a}, \mathbf{e}, \mathbf{f} ; 2 \mu \mathrm{m}$ in $\mathbf{b}$ and $5 \mu \mathrm{m}$ in $\mathbf{c}$

green. This difference may be associated with the abundance of phenolic substances in the gland exudate of $V$. intermedia. Phenolic substances in the gland cells can be associated with protection against herbivores and pathogens (Subramaniam et al. 1990). The presence of oils in the gland exudates makes the secretion more fluid and therefore more easily collected by bees. This facilitated harvest has already been noted for the floral resin produced in 
Table 2 Endophytic bacteria profiles per vacuole area $\left(\mu \mathrm{m}^{2}\right)$ in Barbacenia flava and Vellozia intermedia for the developmental stages (A-D) related to the glands' secretory period, expressed as mean \pm standard deviation $(\mathrm{SD})$, minimum $(\min )$ and maximum (max) values $(n=$ vacuole number)

\begin{tabular}{|c|c|c|c|c|c|c|}
\hline & \multicolumn{3}{|l|}{ Stages A, B } & \multicolumn{3}{|l|}{ Stages C, D } \\
\hline & Mean \pm SD & Min-max & $n$ & Mean \pm SD & Min-max & $n$ \\
\hline Barbacenia flava & $0.06 \pm 0.07$ & $(0.01-0.02)$ & 15 & $0.45 \pm 0.51$ & $(0.08-1.7)$ & 15 \\
\hline Vellozia intermedia & $0.02 \pm 0.18$ & $(0.004-0.05)$ & 10 & $0.25 \pm 0.10$ & $(0.06-0.6)$ & 10 \\
\hline
\end{tabular}
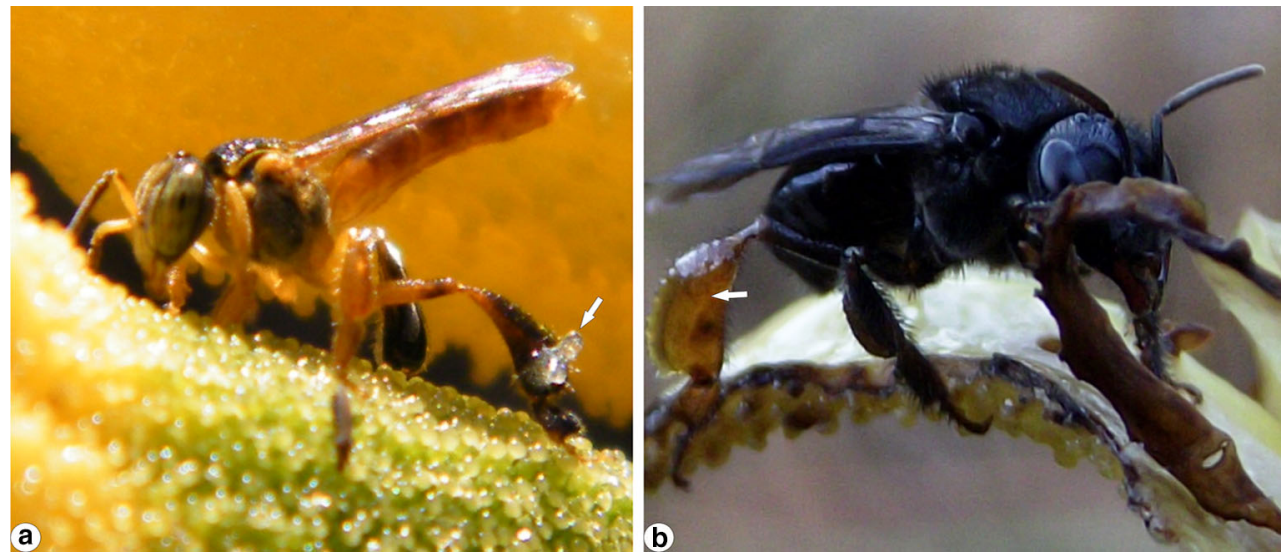

Fig. 7 Barbacenia flava flowers being visited by Tetragonisca angustula (a) and Trigona spinipes (b). Note the corbiculae full of resin (white arrows)

Clusia flowers (Sá-Haiad et al. 2015). Resin is apparently collectable and workable only as a viscid liquid; as soon as it hardens, it presumably ceases to be attractive to bees (Armbruster 1984).

The viscid secretion produced by glands localised in the distal region on the external tepals, keeps the tepals united during the bud stage. This close association helps protect the developing reproductive organs.

The presence of thick walls, impregnated with suberin in the stalk tip, forming a kind of thickened ring, may represent an apoplastic barrier, in addition to its function as a support for the secretory head, mainly in B. flava. Thickened walls may also have a protective function, preventing damage to the secretory tissue by the visitors, as hypothesised for the colleters of Croton glandulosus (Machado et al. 2015).

Oil-resin production occurs in very young floral buds, through till the development of the fruit. This indicates gland-cell activity persists from formation throughout this period. Our ontogenetic and ultrastructural analyses show that the hypanthium glands become senescent during flower development and are continuously replaced by new glands originating in the stalks of the mature glands.

Our results show that the subcellular characteristics of the glands at the secretory stage are consistent with the mixed composition of their exudates, as detected using histochemical tests. Some features, such as abundant cytoplasmic oil bodies, polymorphic plastids devoid of inner membranes and filled with osmiophilic inclusions, periplastidial endoplasmic reticulum together with the proliferation of smooth endoplasmic reticulum, have been described in many oil-resin secreting glands (Sá-Haiad et al. 2015 and literature therein). Similar features have been also associated with monoterpene secreting glands (Gleizes et al. 1982, 1983; Cheniclet and Carde 1985; Kleinig 1989; Turner et al. 1999; Machado et al. 2006; Possobom et al. 2015).

The presence of free ribosomes, polyribosomes, Golgi bodies and rough endoplasmic reticulum elements in the cytoplasm of secretory cells characterise hydrophilic secretions (Fahn 1979), probably polysaccharides and protein, previously detected by histochemistry. Furthermore, such characteristics indicate the high metabolic status of the secretory cells needed for terpene biosynthesis (Turner and Croteau 2004) and for the synthesis of the enzymes that participate in the middle lamella degradation processes, necessary for the development of wall gaps (Ascensão et al. 1997; Machado et al. 2006).

Terpenes can act as insect attractants, especially for bees, which are particularly sensitive to floral scents (Harborne 1997). This activity is reinforced by the observation that visits to $B$. flava and $V$. intermedia flowers 
occur only under certain conditions, specifically during the hottest hours of the day. The increase in air temperature (Hansted et al. 1994; Jakobsen and Olsen 1994), the increase in irradiance and the decrease in moisture (Jakobsen and Olsen 1994), are conditions associated with increased emission rates of volatiles (Majetic et al. 2009) and hence to greater olfactory attraction for bees (Matile and Altenburger 1988; Altenburger and Matile 1990; Loughrin et al. 1990; Jakobsen and Olsen 1994; Hansted et al. 1994).

Signals of granulocrine and eccrine mechanisms of elimination of the secretion from the protoplast were observed in the glands of both species studied here. The abundance of vesicles, originated from Golgi bodies or endoplasmic reticulum, their proximity and fusions signs to the plasma membrane and the subsequent accumulations of contents outside the protoplast, i.e. in the periplasmic space, indicate a granulocrine pathway secretion (Fahn 1979, 2000; Evert 2006). In addition, the presence of lipid bodies scattered in the cytoplasm and in the periplasmic space, also suggests the occurrence of an eccrine mechanism of secretion where the molecules pass the plasma membrane directly as a result of a concentration gradient or by an active transport (Fahn 1979; Evert 2006). In fact, in a same gland cell producing mixed secretions, polysaccharides and proteins collected in membrane bound vesicles are eliminated from the cytoplasm by exocytosis, typical of the granulocrine secretion, while oils and resin components are able to traverse the plasma membrane by the eccrine secretion (Rodrigues et al. 2011; Machado et al. 2012; SáHaiad et al. 2015). Additionally, products of secretion can be transported by the endoplasmic reticulum, which is able to merge with the plasma membrane and release the secretion outside the protoplast (Fahn 1988 and literature therein). Following the accumulation in the periplasmic space, the secretion cross the outer periclinal wall of the epidermal cells and is released on the surface. In the head secretory cells, there was neither stretching of the cuticle nor the appearance of subcuticular spaces.

The study clearly shows that the outer cell walls of the epidermis are directly involved in the release of the substances to the gland surface. It is notable that in both species the cuticle has a dense fibrillar network and forms microchannels which give it a 'spongy' appearance. The spongy cuticle combined with pressure caused by the accumulation of material in the periplasmic space may facilitate the passage of the secretion stream through the intact outer periclinal walls, as hypothesised by Paiva (2009).

Bacteria were consistently found inside the oil-resin gland cells, in both studied Velloziaceae species. Endophytic bacteria have been isolated from a large diversity of plants. It is thought likely, there is no plant species totally devoid of endophytes (Rosenblueth and Martínez-Romero
2006), mainly those plants adapted to grow under lownitrogen soil conditions (Beltran-Garcia et al. 2014). It is remarkable that the plants studied here, live in area characterised by soils of high acidity that lack significant clay and silt components, and so are of very low nutrient status (Alves et al. 2014a). Nevertheless, they exhibit vegetative propagation and seem to be healthy. In fact, bacteria apparently cause no damage to the development and function of the glands, as is known to the endophytic bacteria (Reinhold-Hurek and Hurek 2011). The identity of these bacteria, their biological significance, and the nature of any interactions with the host plant, with the resin, and with the bees has yet to be determined.

Leaf-bacteria symbioses are less common and have been described in tropical genera belonging to Myrsinaceae, Rubiaceae, Dioscoreaceae, and Styracaceae. In the three first families, the bacteria reside in the apical region of the shoot that is permanently filled with mucilage secretion produced by specialized trichomes (Miller et al. 1983, 1984; Miller and Reporter 1987; Van Oevelen et al. 2003). Similar to described for Styrax camporum (Machado et al. 2014), in the studied Velloziaceae species bacteria reside inside specialized glands and this fact may be advantageous to the symbiont in terms of protection and nourishment. This assumption becomes more attractive when one considers the high temperatures and light intensities and low humidity of the Campos Rupestres. We suggest that the oil-resin glands of Velloziaceae species offer a suitable model with which to investigate such plant:endophytic bacterial associations.

We record here for the first time the interaction between the oil-resin glands in the pedicels, hyphantia, and tepals of Velloziaceae and the stingless bees Trigona spinipes and Tetragonisca angustula. Many bees, including the Meliponina, collect plant resins, from both the vegetative parts and the flowers, for nest building (Armbruster and Webster 1979 and literature therein). Here, they may benefit from the fungicidal and bactericidal properties of the resins (Langenheim 2003).

Although the glands are present in the flower, they are not involved in the pollination process, but function as an extranuptial resource for Trigona spinipes and Tetragonisca angustula. The secretions studied here have the same characteristics that have led to the evolution of floral resins as a reward: the malleability, as a result of the mixed secretion including oil and resin (Porto et al. 2000), and the predictability, since bees can associate resource availability to flower attributes (Simpson and Neff 1983). Therefore, we believe this interaction is the result of the bees' opportunism, since floral resins are a particularly valuable resource for both Apidae and Megachilidae bees (Armbruster 1984).

On the other hand, it has been suggested that resinsecreting glands may also deter herbivory (Feeny 1976; 
Swain 1979). In the species studied here, a deterrent role for the resin, as a protection against herbivores, seems unlikely, as the flowers are heavily predated and parasitised by many insect taxa. In fact, ca. $56 \%$ of buds $(n=85)$ and $62 \%$ of flowers $(n=138)$ of $V$. intermedia and $54 \%$ of buds $(n=51)$ and $75 \%$ of flowers $(n=189)$ of $B$. flava exhibited some degree of feeding damage (Sadala-Castilho, unpublished data). However, it should be remembered that T. spinipes is often cited as a pillager of floral resources, causing damage to reproductive structures (Renner 1983). Possibly, the long period of time devoted to the collection of resin by this bee, may have some effect in reducing flower damage and increasing reproductive success, although this effect remains to be tested.

The sticky resin secreted by trichomes located in the calyx of Plumbago flowers is still interpreted as an important attribute for fruit dispersal by animals, since fruits are shed together with a persistently secreting calyx (Fahn 1979). This is not the case for the Velloziaceae species, because oil-resin glands are not active during fruit dehiscence and the seeds dispersion is autochoric.

Other benefits suggested for superficial resin glands in plants, are associated with reduced desiccation, ultraviolet screening, increased light reflection and reduced internal temperature (Dell 1977; Langenheim 2003). Dell and McComb (1987) observed that surface resinous secretions are more prominent in plants occurring in dry habitats, and thus can be included among the xeromorphic features of such plants. Thus, the ecological role of the resin in the species studied here appears to be more related to the xeric environment where they occur, than to a strong interaction with the Meliponina bees that use it, considering that both species are common in the Brazilian Campos Rupestres, a unique ecosystem characterised by a well-delimited dry season, high irradiance and high vapor pressure deficit.

\begin{abstract}
Acknowledgments We thank the editors and the anonymous reviewers for their helpful comments on an earlier version of this paper. We also thank Dr. Renato de Mello-Silva for plant identification and Dr. Felipe Vivallo for bee identification. We also thank the Electron Microscopy Centre (CME) IBB, UNESP and its technicians for assistance with the ultrastructural analyses. This study forms part of the master's thesis of R. S. C., which was carried out in the Postgraduate Program in Biological Sciences (Botany) of the Universidade Federal do Rio de Janeiro (UFRJ), Museu Nacional, and was supported by CAPES (Coordenação de Aperfeiçoamento de Pessoal de Nível Superior). B. S. H. was supported by research Grants from FAPERJ APQ1 (Proc. E-26/111.207/2014) and MCTI/CNPQ/ Universal (Proc. 447624/2014-8) and S. R. M. received Grants from CNPq.
\end{abstract}

\section{Compliance with ethical standards}

Conflict of interest The authors declare that they have no conflict of interest.

\section{References}

Altenburger R, Matile P (1990) Further observations on rhythmic emission of fragrance in flowers. Planta 180:194-197

Alves RJV, Silva NG, Oliveira JA, Medeiros D (2014a) Circumscribing campo rupestre-megadiverse Brazilian rocky montane savannas. Braz J Biol 74:355-362

Alves RJV, Guimarães AR, Rezende CM, Braga LS, Silva NGA (2014b) New giant Vellozia (Velloziaceae) from Minas Gerais, Brazil with comments on the $V$. compacta complex and conservation. Phytotaxa 172:13-21

Amaral LIV, Pereira MF, Cortelazzo AL (2001) Formação das substâncias de reserva durante o desenvolvimento de sementes de urucum (Bixa orellana L.-Bixaceae). Acta Bot Brasil $15: 125-132$

Armbruster WS (1984) The role of resin in angiosperm pollination: ecological and chemical considerations. Amer J Bot 71:1149-1160

Armbruster WS, Webster GL (1979) Pollination of two species of Dalechampia (Euphorbiaceae) in Mexico by euglossine bees. Biotropica 11:278-283

Ascensão L, Marques N, Pais MS (1997) Peltate glandular trichomes of Leonotis leonurus leaves: ultrastructure and histochemical characterization of secretions. Int J Pl Sci 158:249-258

Beltran-Garcia MJ, White JF Jr, Prado FM, Prieto KR, Yamaguchi LF, Torres MS, Di Mascio P (2014) Nitrogen acquisition in Agave tequilana from degradation of endophytic bacteria. Sci Rep 4:6938. doi:10.1038/srep06938

Cheniclet C, Carde JP (1985) Presence of leucoplasts in secretory cells and of monoterpenes in the essential oil: a correlative study. Israel J Bot 34:219-238

Cortelazzo AL, Vidal BC (1991) Soybean seed proteins: detection in situ and mobilization during germination. Braz J Bot 14:27-34

Dafni A, Keavan PG, Husband BC (2005) Practical pollination biology. Enviroquest Ltda, Cambridge

Dell B (1977) Distribution and function of resins and glandular hairs in Western Australian plants. J Roy Soc Western Australia 59:119-123

Dell B, McComb AJ (1987) Plant resins-their formation, secretion and possible functions. Advances Bot Res 6:277-316

Evert RF (2006) Esau's plant anatomy: meristems, cells, and tissues of the plant body: their structure, function, and development, 3rd edn. Wiley, Hoboken

Fahn A (1979) Secretory tissues in plants. Academic Press, London

Fahn A (1988) Secretory tissues in vascular plants. New Phytol 108:229-257

Fahn A (2000) Structure and function of secretory cells. Advances Bot Res 31:37-75

Feder N, O'Brien TP (1968) Plant microtechnique: some principles and new methods. Amer J Bot 55:123-142

Feeny P (1976) Plant apparency and chemical defense. In: Wallace JW, Mansell RL (eds) Biochemical interaction between plants and insects. Recent advances in phytochemistry, vol 10. Plenum Press, New York, pp 1-40. doi:10.1007/978-1-4684-2646-5_1

Gabe M (1968) Techniques histologiques. Masson \& Cie, Paris

Gahan PB (1984) Plant histochemistry and cytochemistry-an introduction. Academic Press, London

Giulietti AM, Pirani JR (1988) Patterns of geographic distribution of some plant species from the Espinhaço Range, Minas Gerais and Bahia, Brazil. In: Vanzolini PE, Heyer WR (eds) Proceedings of a Workshop on Neotropical Distribution Patterns. Academia Brasileira de Ciências, Rio de Janeiro, pp 39-69

Gleizes M, Marpeau A, Pauly G, Bernard-Dagan C (1982) Role of acyclic compounds in monoterpene biosynthesis in Pinus pinaster. Phytochemistry 21:2641-2644 
Gleizes M, Pauly G, Carde JP, Marpeau A, Bernard-Dagan C (1983) Monoterpene hydrocarbon biosynthesis by isolated leucoplasts of Citrofortunella mitis. Planta 159:373-381

Gregory M, Baas P (1989) A survey of mucilage cells in vegetative organs of the dicotyledons. Israel J Bot 38:125-174

Hammond CT, Mahlberg PG (1973) Morphology of glandular hairs of Cannabis sativa from scanning electron microscopy. Amer J Bot 60:524-528

Hansted L, Jakobsen HB, Olsen CE (1994) Influence of temperature on the rhythmic emission of volatiles from Ribes nigrum flowers in situ. Pl Cell Environ 17:1069-1072

Harborne JB (1997) Biochemical plant ecology. In: Dey PM, Harborne JB (eds) Plant Biochemistry. Academic Press, London, pp 503-516

Jacobi CM, Del Sarto MCL (2007) Pollination of two species of Vellozia (Velloziaceae) from high-altitude quartzitic grasslands, Brazil. Acta Bot Brasil 21:325-333

Jakobsen HB, Olsen CE (1994) Influence of climatic factors on emission of flower volatiles in situ. Planta 192:365-371

Jensen WA (1962) Botanical histochemistry: principles and practice. WH Freeman \& Co., San Francisco

Johansen DA (1940) Plant microtechnique. McGraw-Hill Book Company, New York

Kearns CA, Inouye DW (1993) Techniques for pollination biologists. University Press of Colorado, Niwot

Kleinig H (1989) The role of plastids in isoprenoid biosynthesis. Annual Rev. Pl Physiol Pl Molec Biol 40:39-59

Langenheim JH (2003) Plant resins: chemistry, evolution, ecology and ethnobotany. Timber Press, Portland

Langeron M (1949) Precis de microscopie. Masson \& Cie, Paris

Loughrin JN, Hamilton-Kemp TR, Andersen RA, Hildebrand DF (1990) Volatiles from flowers of Nicotiana sylvestris, $N$. otophora and Malus domestica: headspace components and day/night changes in their relative concentrations. Phytochemistry 29:2473-2477

Machado SR, Gregório EA, Guimarães E (2006) Ovary peltate trichomes of Zeyheria montana (Bignoniaceae): developmental ultrastructure in relation to function. Ann Bot (Oxford) 97:357-369

Machado SR, Barreiro DP, Rocha JF, Rodrigues TM (2012) Dendroid colleters on vegetative and reproductive apices in Alibertia sessilis (Rubiaceae) differ in ultrastructure and secretion. Flora Morphol Distrib Funct Ecol Pl 207:868-877

Machado SR, Teixeira SP, Rodrigues TM (2014) Bacterial leaf glands in Styrax camporum (Styracaceae): first report for the family. Bot Int J Pl Biol 92:403-411

Machado SR, Paleari LM, Paiva EAS, Rodrigues TM (2015) Colleters on the inflorescence axis of Croton glandulosus (Euphorbiaceae): structural and functional characterization. Int J Pl Sci 176:86-93

Maclean RC, Ivemey-Cook WR (1952) Textbook of practical botany. Longmans Greenands Co., London

Majetic CJ, Raguso RA, Ashman TL (2009) The sweet smell of success: floral scent affects pollinator attraction and seed fitness in Hesperis matronalis. Funct Ecol 23:480-487

Matile P, Altenburger R (1988) Rhythms of fragrance emission in flowers. Planta 174:242-247

Mello-Silva R (1995) Aspectos Taxonômicos, Biogeográficos, Morfológicos e Biológicos das Velloziaceae de Grão-Mogol, Minas Gerais, Brasil. Bol Bot Univ São Paulo 14:49-79

Mello-Silva R (2004) Velloziaceae. In: Smith N, Mori SA, Henderson A, Stevenson DW, Heald SV (eds) Flowering plants of the neotropics. Princeton University Press, Princeton, pp 490-491

Mello-Silva R (2005) Morphological analysis, phylogenies and classification in Velloziaceae. Bot J Linn Soc 148:157-173

Menezes NL (1973) Natureza dos apêndices petalóides em Barbacenioideae (Velloziaceae). Bol Zool Biol Mar NS 30:713-755
Menezes NL (1980) Evolution in Velloziaceae, with special reference to androecial characters. In: Brickell CD, Cutler DF, Gregory M (eds) Petaloid monocotyledons. Linnean society symposium serries, vol 8. Academic Press, London, pp 117-139

Menezes NL (1988) Evolution of the anther in the family Velloziaceae. Bol Bot Univ São Paulo 10:33-41

Miller IM, Reporter M (1987) Bacterial leaf symbiosis in Dioscorea sansibarensis: morphology and ultrastructure of the acuminate leaf glands. Pl Cell Environ 10:413-424

Miller IM, Scott A, Gardner IC (1983) Leaf nodule development in Psychotria kirkii Hiern (Rubiaceae). Ann Bot (Oxford) 52:791-802

Miller IM, Gardner IC, Scott A (1984) Structure and function of trichomes in the shoot tip of Ardisia crispa (Thunb.) A.DC. (Myrsinaceae). Bot J Linn Soc 88:223-236

Montserrat L, Mello-Silva R (2013) Velloziaceae do Parque Estadual de Ibitipoca, Minas Gerais, Brasil. Bol Bot Univ São Paulo 31:131-139

Paiva EAS (2009) Ultrastructure and post-floral secretion of the pericarpial nectaries of Erythrina speciosa (Fabaceae). Ann Bot (Oxford) 104:937-944

Porto ALM, Machado SMF, Oliveira CMA, Bittrich V, Amaral MCA, Marsaioli AJ (2000) Polyisoprenylated benzophenones from Clusia floral resins. Phytochemistry 55:755-768

Possobom CCF, Guimarães E, Machado SR (2015) Structure and secretion mechanisms of floral glands in Diplopterys pubipetala (Malpighiaceae) a neotropical species. Flora Morphol Distrib Funct Ecol Pl 211:26-39

Reinhold-Hurek B, Hurek T (2011) Living inside plants: bacterial endophytes. Curr Opin Pl Biol 14:435-443

Renner S (1983) The widespread occurrence of anther destruction by Trigona bees in Melastomataceae. Biotropica 15:251-256

Reynolds ES (1963) The use of lead citrate at high $\mathrm{pH}$ as an electronopaque stain in electron microscopy. J Cell Biol 17:208

Rodella LG, Tarifa JR (2002) Clima da Serra do Ibitipoca, MG. GEOUSP_Espaço e. Tempo 11:101-113

Rodrigues TM, Teixeira SP, Machado SR (2011) The oleoresin secretory system in seedlings and adult plants of copaíba (Copaifera langsdorffii Desf., Leguminosae-Caesalpinioideae). Flora Morphol Distrib Funct Ecol Pl 206:585-594

Rosenblueth M, Martínez-Romero E (2006) Bacterial endophytes and their interactions with hosts. Molec Pl Microbe Interact 19:827-837

Sá-Haiad B, Silva CP, Paula RCV, Rocha JF, Machado SR (2015) Androecia in two Clusia species: development, structure and resin secretion. Pl Biol (Stuttgart) 17:816-824

Sajo MG, Mello-Silva R, Rudall PJ (2010) Homologies of floral structures in Velloziaceae with particular reference to the corona. Int J Pl Sci 171:595-606

Sazima M (1978) Biologia floral de espécies de Velloziaceae na Serra do Cipó, Minas Gerais. PhD Thesis, Universidade de São Paulo, São Paulo

Sazima M, Sazima I (1990) Hummingbird pollination in two species of Vellozia (Liliiflorae: Velloziaceae) in southeastern Brazil. Bot Acta 103:83-86

Schindelin J, Arganda-Carreras I, Frise E, Kaynig V, Longair M, Pietzsch T, Preibisch S, Rueden C, Saalfeld S, Schmid B, Tinevez JY, White DJ, Hartenstein V, Eliceiri K, Tomancak P, Cardona A (2012) Fiji: an open-source platform for biologicalimage analysis. Nat Meth 9:676-682

Simpson BB, Neff JL (1983) Evolution and diversity of floral rewards. In: Jones CE, Little RJ (eds) Handbook of experimental pollination biology. Van Nostrand Reinhold Company Inc, New York, pp 142-159

Subramaniam S, Marti T, Khorana HG (1990) Protonation state of Asp (Glu)-85 regulates the purple-to-blue transition in 
bacteriorhodopsin mutants Arg-82 $\rightarrow$ Ala and Asp- $85 \rightarrow$ Glu: the blue form is inactive in proton translocation. Proc Natl Acad Sci USA 87:1013-1017

Swain T (1979) Tannins and lignins. In: Rosenthal GA, Janzen DH (eds) Herbivores: their interactions with secondary plant metabolites. Academic Press, London, pp 3-19

Taboga SR, Vilamaior PSL (2013) Citoquímica. In: Carvalho HF, Recco-Pimentel SM (eds) A célula. Editora Manole, Barueri

Turner GW, Croteau R (2004) Organization of monoterpene biosynthesis in Mentha. Immunocytochemical localizations of geranyl diphosphate synthase, limonene-6-hydroxylase, isopiperitenol dehydrogenase, and pulegone reductase. Pl Physiol (Lancaster) 136:4215-4227

Turner G, Gershenzon J, Nielson EE, Froehlich JE, Croteau RB (1999) Limonene synthase, the enzyme responsible for monoterpene biosynthesis in peppermint, is localized in oil gland secretory cells. Pl Physiol (Lancaster) 120:879-886

Van Oevelen S, De Wachter R, Robbrecht E, Prinsen E (2003) Induction of a crippled phenotype in Psychotria (Rubiaceae) upon loss of the bacterial endophyte. Bulg J Pl Physiol 3-4(Special Issue):242-247 